\title{
Penalaran proporsional siswa kelas VII
}

\author{
Yandika Nugraha1 ${ }^{1}$ Imam Sujadi, Pangadi ${ }^{2}$
}

\begin{abstract}
Abstrak: Penelitian ini merupakan penelitian kualitatif deskriptif yang bertujuan untuk mendeskripsikan karakteristik penalaran proporsional siswa. Subjek penelitian adalah siswa kelas VII SMP Negeri 1 Tasikmadu Kabupaten Karanganyar. Prosedur pemilihan subjek dengan cara purposive sampling. Pengumpulan data dilakukan dengan cara think aloud method. Validitas data menggunakan triangulasi waktu. Teknik analisis data dilakukan dengan cara: (1) mengelompokkan data dalam 2 kategori, kemudian mereduksi data yang tidak termasuk dalam 2 kategori tersebut, (2) menyajikan data dalam teks naratif, dan (3) menyimpulkan karakteristik penalaran proporsional siswa kemudian membandingkan subjek yang berada pada level yang sama. Berdasarkan penelitian yang dilakukan pada enam subjek siswa kelas VII SMP Negeri Tasikmadu, terdapat empat siswa yang sudah bisa bernalar kuantitatif yaitu mampu memanipulasi situasi perbandingan dengan menggunakan suatu bilangan dan dua siswa menggunakan perkalian silang tetapi tidak sepenuhnya memahami hubungan invarian dan kovarian.
\end{abstract}

Kata Kunci: Penalaran Proporsional; Pemecahan Masalah; Bernalar Kuantitatif; Perkalian Silang; Invarian dan Kovarian

\begin{abstract}
This descriptive qualitative research is aimed at describing the characteristics of students proportional reasoning. The subjects are the seventh grade students at SMP Negeri 1 Tasikmadu Karanganyar. The subjects are selected through purposive sampling methods. Data collection applies think aloud method. Time triangulation is used for data validation. Data is analyzed by: (1) classifying data in two categories then reducing them which do not belong to both categories, (2) presenting the data in narrative text, and (3) summarizing the characteristics of students proportional reasoning then comparing the subjects based on same level. The research shows that 4 of 6 students are able to reason quantitatively which mean that they can manipulate the proportional situation using number and the remaining students use cross product but they did not fully understand about the relation of invariant and covariant.
\end{abstract}

\footnotetext{
${ }^{1}$ IAIN Mataram, JI Gajah Mada 100 Mataram, Indonesia, yandika310189@yahoo.com

2 Universitas Sebelas Maret Surakarta, JI Ir Sutami Surakarta, Indonesia
} 
Keywords: Proportional Reasoning; Problem Solving; Reason Quantitatively; Cross Product; Invariant and Covariant

\section{A. Pendahuluan}

Dalam penggunaan operasi hitung penjumlahan dan perkalian, terkadang siswa masih bingung kapan seharusnya menggunakan penjumlahan atau perkalian. Untuk mengubah suatu pandangan siswa dari hubungan penjumlahan menjadi perkalian sangatlah sulit. Menurut Lamon (dalam Singh, 2010), para siswa ternyata masih sering menggunakan strategi penjumlahan dalam menyelesaikan suatu masalah matematika dimana seharusnya menggunakan strategi perkalian. Pemahaman mengenai strategi perkalian ini sangat penting, salah satunya merupakan indikasi dari kemampuan mengenai penalaran proporsional. Menurut Walle (2007), "penalaran proporsional mewakili kemampuan untuk memulai memahami hubungan perkalian dimana sebagian besar konsep aritmetika biasanya berdasarkan penjumlahan". Hal senada juga diungkapkan oleh Kilpatrick dkk (2001), "memahami hubungan-hubungan mendasar pada suatu situasi proporsional dan sekaligus menggunakan hubungan-hubungan tersebut dinamakan dengan penalaran proporsional". Penalaran proporsional diambil dari kata penalaran atau berpikir secara logis dan proporsional atau situasi perbandingan, sehingga dapat diartikan sebagai berpikir secara logis dalam situasi perbandingan. Hubunganhubungan dalam situasi proporsional yang dimaksud yaitu berkaitan dengan konsep rasio dan proporsi. Menurut Walle (2007), rasio merupakan sebuah bilangan yang menghubungkan dua kuantitas atau ukuran dalam situasi tertentu terhadap sebuah hubungan perkalian, sedangkan proporsi merupakan pernyataan kesetaraan dua rasio. Dalam bentuk formal suatu proporsi dapat dituliskan $\frac{a}{b}=\frac{c}{d}$.

Dalam kehidupan sehari-hari, banyak sekali permasalahan mengenai situasi proporsional, di antaranya yaitu perbandingan dalam penetapan harga, penggunaan skala dalam peta, penyelesaian persoalan tentang persentase, penggunaan skala dalam merancang suatu bangunan, dan masih banyak lagi. Dalam cabang ilmu matematika, penalaran proporsional memegang peranan penting karena merupakan dasar dari berbagai materi pembelajaran, di antaranya yaitu pecahan, aljabar, kesebangunan, dan peluang (Walle, 2007).

Untuk mengetahui sejauh mana penalaran mengenai situasi proporsional, Langrall dan Swafford (2000) membuat empat level penalaran proporsional, yaitu level $0,1,2$, dan 3 , dimana pada tiap-tiap 
level memiliki karakteristik yang berbeda-beda. Pada level 0 , siswa belum bisa menggunakan penalaran proporsional, karena mereka masih terpaku dengan cara menebak-nebak atau menggunakan bantuan visual. Pada level 1 , siswa menggunakan gambar, manipulasi, atau model matematika yang sesuai dengan masalah yang diberikan. Siswa juga dapat membuat perbandingan kualitatif yaitu melipatgandakan masing-masing nilai yang membentuk suatu rasio. Pada level 2, siswa dapat memanipulasi situasi perbandingan menggunakan bilangan. Untuk memecahkan masalah perbandingan, siswa level 2 mampu menggunakan kombinasi tiap-tiap unit, menemukan dan menggunakan nilai satuan per unit, mengidentifikasi atau menggunakan faktor skalar, menggunakan bantuan tabel, menggunakan pecahan senilai, dan membangun kedua ukuran. Pada level 3, siswa dapat menetapkan suatu proporsi dengan menggunakan variabel dan memecahkan variabel tersebut dengan menggunakan aturan perkalian silang. Siswa juga sepenuhnya mengerti hubungan kovarian dan invarian. Menurut Langrall dan Swafford (2000), invarian merupakan hubungan antara dua kuantitas yang memiliki nilai tetap sama, sedangkan kovarian yaitu dua ukuran pada tiap-tiap rasio bervariasi bersama-sama.

Berdasarkan penelitian yang dilakukan oleh Langrall dan Swafford (2000), penelitian ini bertujuan untuk mengetahui karakteristik dari level penalaran proporsional siswa kelas VII SMP Negeri 1 Tasikmadu Kabupaten Karanganyar.

\section{B. Metode Penelitian}

Penelitian ini dilaksanakan di SMP Negeri 1 Tasikmadu Kabupaten Karanganyar. Penelitian ini dapat digolongkan ke dalam jenis penelitian kualitatif studi kasus terpancang. Menurut H. B. Sutopo (2006: 137-139), studi kasus mengarah pada pendeskripsian secara rinci dan mendalam mengenai suatu kondisi yang sebenarnya terjadi di lapangan. Pada penelitian yang sifatnya terpancang memiliki batasan yang tegas dan jelas karena memiliki fokus penelitian yang sudah terarah. Subjek dalam penelitian ini yaitu siswa kelas VII. Pemilihan siswa kelas VII sebagai subjek penelitian dengan alasan: (1) siswa kelas VII telah mendapatkan pembelajaran perbandingan, (2) siswa kelas VII sudah mempelajari materi yang dibutuhkan untuk mempelajari perbandingan yaitu pecahan. Pemilihan subjek dalam penelitian ini dimaksudkan untuk menjaring informasi sebanyak mungkin dari berbagai sumber yang digunakan untuk merumuskan tingkat-tingkat penalaran proporsional, serta mengungkapkan karakteristik dari penalaran proporsional siswa dalam memecahkan masalah mengenai proporsi. Berdasarkan hal ini, penelitian 
ini dapat digolongkan ke dalam penelitian kualitatif yang bersifat deskriptif. Pada penelitian ini, data dikumpulkan langsung oleh peneliti, sehingga instrumen utama penelitian yaitu peneliti sendiri sebagai pewawancara yang dibantu dengan instrumen bantu berupa soal tes pemecahan masalah perbandingan yang sebelumnya telah divalidasi oleh dua orang dosen yang telah menempuh program doktoral. Teknik pengumpulan data dalam penelitian ini, yaitu menggunakan think aloud method, yaitu siswa diminta untuk mengungkapkan ekpresi verbal tentang ide yang dipikirkan ketika menyelesaikan soal perbandingan.

Tahap analisis data dilakukan setelah penggalian data yang diperoleh dianggap cukup untuk memenuhi maksud dan tujuan penelitian. Setelah data yang dianggap relevan dengan masalah yang diteliti, data kemudian dianalisis kembali secara lebih mendalam kemudian ditarik sebuah kesimpulan yang mudah dipahami oleh diri sendiri dan orang lain. Metode analisis yang digunakan adalah analisis data kualitatif. Dalam penelitian kualitatif, analisis data dilakukan sejak awal dan sepanjang proses penelitian berlangsung. Proses analisis data pada penelitian ini dilakukan dengan langkah-langkah sebagai berikut ini:

1. Subjek ke-j $(j=1,2,3, \ldots)$ diberikan soal mengenai masalah perbandingan yang pertama. Subjek diminta untuk mengerjakan soal dengan mengungkapkan ide pikiran mereka secara lisan sehingga diperoleh data lisan dan tertulis. Setelah didapatkan data penelitian, kemudian dilakukan identifikasi data, yaitu dituliskan data yang terorganisir dan terkategori sehingga dapat ditarik suatu kesimpulan. Kumpulan data dikategorikan menjadi dua yaitu pemecahan masalah menggunakan strategi informal dan strategi formal. Indikator untuk strategi informal yaitu menggunakan bantuan gambar, bantuan tabel, mencari nilai satuan, menggunakan pecahan senilai, menggunakan faktor skalar, dan menggunakan kombinasi dari tiap-tiap nilai. Indikator untuk strategi formal yaitu menggunakan perkalian silang dan sepenuhnya memahami hubungan invarian dan kovarian. Langkah selanjutnya yaitu menyajikan data yang disusun secara baik, runtut sehingga mudah dilihat, dibaca, dan dipahami tentang suatu kejadian atau peristiwa dalam bentuk teks naratif. Selanjutnya yaitu menarik kesimpulan dari data yang dikumpulkan dan memverifikasi kesimpulan tersebut. Subjek ke-j $(j=1,2,3, \ldots)$ selanjutnya diberikan soal mengenai masalah perbandingan yang kedua. Data hasil tes pemecahan masalah kedua dianalisis seperti data tes pemecahan masalah pertama. 
2. Hasil analisis data tes pertama dan kedua ditriangulasikan dengan membedakan hasil pada tes pertemuan pertama dengan pertemuan yang kedua untuk mendapatkan data yang valid. Data yang valid digunakan untuk mengetahui karakteristik level penalaran proporsional siswa dengan cara mencocokkan karakteristik yang ditemukan dengan teori yang ada pada kajian teori.

3. Langkah terakhir yaitu membandingkan karakteristik dari subjek yang memenuhi level penalaran proporsional yang sama. Karakteristik yang sama merupakan temuan utama penelitian, dan jika terdapat karakteristik yang berbeda, maka menjadi temuan lain dalam penelitian. Untuk mencari level penalaran proporsional dengan perbandingan tetap yaitu membandingkan secara tetap kategori data dengan kategori data yang lain (Lexy Johannes Moleong, 2012: 288). Menurut Imam Sujadi (2010: 46) untuk mengetahui konsistensi dari hasil penelitian dengan kajian teori yang sudah diberikan dapat menggunakan perbandingan tetap. Dalam penelitian ini perbandingan tetap dilakukan dengan membandingkan karakteristik yang valid dengan teori yang sudah dirumuskan untuk mengetahui level penalaran proporsionalnya. Setelah ditemukan level penalaran proporsional, selanjutnya membandingkan karakteristik penalaran proporsional antar subjek pada level yang sama. Karakteristik yang sama dari beberapa subjek dengan teori yang diajukan merupakan karakteristik dari level penalaran proporsional, tetapi jika terdapat karateristik yang berbeda namun masih berada dalam level tersebut, maka akan dijadikan temuan lain penelitian. Temuan lain ini diharapkan akan menjadi temuan baru dalam penelitian mengenai penalaran proporsional.

\section{Temuan dan Pembahasan}

Penentuan subjek dilakukan dengan terlebih dahulu berkonsultasi dengan guru matematika kelas VII SMP Negeri 1 Tasikmadu untuk mendapatkan siswa yang sudah mendapat pembelajaran perbandingan. Berdasarkan hasil konsultasi dengan guru matematika bersangkutan, didapatkan siswa-siswa kelas VII yang sudah mendapatkan pembelajaran perbandingan dan sanggup dijadikan subjek penelitian. Berdasarkan pertimbangan dari guru matematika tentang kemampuan siswa dalam mengemukakan pendapat baik secara lisan maupun tertulis, serta kemampuan matematika siswa sehari-hari, maka selanjutnya dipilih siswa 
yang memenuhi kriteria sebagai subjek penelitian yaitu subjek $F A N, A B W$, LR, IUH, QQ, dan AW. Setelah dilakukan analisis data, ternyata diketahui bahwa subjek FAN, ABW, LR, dan IUH berada pada penalaran proporsional level 2, sedangkan subjek $Q Q$ dan $A W$ berada pada penalaran proporsional level 3. Setelah diketahui karakteristik masing-masing subjek yang valid, kemudian dilakukan perbandingan tetap dengan membandingkan karakteristik dari subjek yang memenuhi level penalaran proporsional yang sama. Karakteristik yang sama merupakan temuan utama penelitian, dan jika terdapat karakteristik yang berbeda, maka menjadi temuan lain dalam penelitian.

Karakteristik dari subjek FAN, ABW, LR, dan IUH yang valid dapat dilihat pada Tabel 1 berikut.

Tabel 1. Perbandingan Karakteristik dari Subjek FAN, ABW, LR, dan IUH

\begin{tabular}{|c|c|c|c|}
\hline Subjek FAN & Subjek ABW & Subjek LR & Subjek IUH \\
\hline $\begin{array}{l}\text { 1. Menggunakan } \\
\text { hasil } \\
\text { perhitungan } \\
\text { untuk } \\
\text { menjawab } \\
\text { soal mengenai } \\
\text { bantuan } \\
\text { media gambar } \\
\text { 2. Menggunakan } \\
\text { hasil } \\
\text { perhitungan } \\
\text { untuk } \\
\text { menjawab } \\
\text { soal mengenai } \\
\text { bantuan } \\
\text { media tabel } \\
\text { 3. Menggunakan } \\
\text { faktor skalar } \\
\text { dalam } \\
\text { memecahkan } \\
\text { masalah } \\
\text { perbandingan. } \\
\text { 4. Menggunakan } \\
\text { nilai satuan } \\
\text { dalam }\end{array}$ & $\begin{array}{l}\text { 1. Menggunakan } \\
\text { hasil } \\
\text { perhitungan } \\
\text { untuk } \\
\text { menjawab } \\
\text { soal } \\
\text { mengenai } \\
\text { bantuan } \\
\text { media } \\
\text { gambar } \\
\text { 2. Dapat } \\
\text { menggunakan } \\
\text { bantuan tabel } \\
\text { dengan } \\
\text { terlebih } \\
\text { dahulu } \\
\text { mencari nilai } \\
\text { satuannya } \\
\text { sebagai faktor } \\
\text { pengalinya } \\
\text { 3. Menggunakan } \\
\text { nilai satuan } \\
\text { dalam } \\
\text { memecahkan }\end{array}$ & $\begin{array}{l}\text { 1. Menggunakan } \\
\text { hasil } \\
\text { perhitungan } \\
\text { untuk } \\
\text { menjawab } \\
\text { soal } \\
\text { mengenai } \\
\text { bantuan } \\
\text { media } \\
\text { gambar } \\
\text { 2. Menggunakan } \\
\text { hasil } \\
\text { perhitungan } \\
\text { untuk } \\
\text { menjawab } \\
\text { soal } \\
\text { mengenai } \\
\text { bantuan } \\
\text { media tabel } \\
\text { 3. Menggunakan } \\
\text { nilai satuan } \\
\text { dalam } \\
\text { memecahkan } \\
\text { masalah } \\
\text { perbandingan }\end{array}$ & $\begin{array}{l}\text { 1. Menggunakan } \\
\text { hasil } \\
\text { perhitungan } \\
\text { untuk menjawab } \\
\text { soal mengenai } \\
\text { bantuan media } \\
\text { gambar } \\
\text { 2. Menggunakan } \\
\text { bantuan tabel } \\
\text { dengan terlebih } \\
\text { dahulu mencari } \\
\text { pecahan } \\
\text { senilainya } \\
\text { kemudian } \\
\text { melipatgandakan } \\
\text { 3. Menggunakan } \\
\text { nilai satuan } \\
\text { dalam } \\
\text { memecahkan } \\
\text { masalah } \\
\text { perbandingan } \\
\text { 4. Menggunakan } \\
\text { pecahan senilai } \\
\text { dalam } \\
\text { memecahan }\end{array}$ \\
\hline
\end{tabular}




\begin{tabular}{|c|c|c|c|}
\hline Subjek FAN & Subjek ABW & Subjek LR & Subjek IUH \\
\hline $\begin{array}{l}\text { memecahkan } \\
\text { masalah } \\
\text { perbandingan } \\
\text { 5. Menggunakan } \\
\text { intuisi atau } \\
\text { perasaan } \\
\text { dalam } \\
\text { memecahkan } \\
\text { masalah } \\
\text { perbandingan } \\
\text { 6. Bisa membuat } \\
\text { bentuk } \\
\text { perbandingan } \\
\text { dengan } \\
\text { menggunakan } \\
\text { rasio dalam } \\
\text { (within ratio) } \\
\text { 7. Tidak bisa } \\
\text { membuat } \\
\text { bentuk } \\
\text { perbandingan } \\
\text { dengan } \\
\text { menggunakan } \\
\text { rasio antara } \\
\text { (between } \\
\text { ratio) } \\
\text { 8. Tidak } \\
\text { sepenuhnya } \\
\text { memahami } \\
\text { hubungan } \\
\text { invarian dan } \\
\text { kovarian }\end{array}$ & $\begin{array}{l}\text { masalah } \\
\text { perbandingan } \\
\text { 4. Bisa } \\
\text { membuat } \\
\text { bentuk } \\
\text { perbandingan } \\
\text { dengan } \\
\text { menggunakan } \\
\text { rasio dalam } \\
\text { (within ratio) } \\
\text { 5. Tidak bisa } \\
\text { membuat } \\
\text { bentuk } \\
\text { perbandingan } \\
\text { dengan } \\
\text { menggunakan } \\
\text { rasio antara } \\
\text { (between } \\
\text { ratio) } \\
\text { 6. Tidak } \\
\text { sepenuhnya } \\
\text { memahami } \\
\text { hubungan } \\
\text { invarian dan } \\
\text { kovarian }\end{array}$ & $\begin{array}{l}\text { 4. Menggunakan } \\
\text { pecahan } \\
\text { senilai dalam } \\
\text { memecahan } \\
\text { masalah } \\
\text { perbandingan } \\
\text { 5. Bisa } \\
\text { membuat } \\
\text { bentuk } \\
\text { perbandingan } \\
\text { dengan } \\
\text { menggunakan } \\
\text { rasio dalam } \\
\text { (within ratio) } \\
\text { 6. Tidak bisa } \\
\text { membuat } \\
\text { bentuk } \\
\text { perbandingan } \\
\text { dengan } \\
\text { menggunakan } \\
\text { rasio antara } \\
\text { (between } \\
\text { ratio) } \\
\text { 7. Tidak } \\
\text { sepenuhnya } \\
\text { memahami } \\
\text { hubungan } \\
\text { invarian dan } \\
\text { kovarian }\end{array}$ & $\begin{array}{l}\text { masalah } \\
\text { perbandingan } \\
\text { 5. Bisa membuat } \\
\text { bentuk } \\
\text { perbandingan } \\
\text { dengan } \\
\text { menggunakan } \\
\text { rasio dalam } \\
\text { (within ratio) } \\
\text { 6. Tidak bisa } \\
\text { membuat } \\
\text { bentuk } \\
\text { perbandingan } \\
\text { dengan } \\
\text { menggunakan } \\
\text { rasio antara } \\
\text { (between ratio) } \\
\text { 7. Tidak } \\
\text { sepenuhnya } \\
\text { memahami } \\
\text { hubungan } \\
\text { invarian dan } \\
\text { kovarian } \\
\text { 8. Kurang tepat } \\
\text { dalam } \\
\text { menggunakan } \\
\text { bentuk } \\
\text { perbandingan } \\
\text { untuk } \\
\text { memecahkan } \\
\text { masalah } \\
\text { perbandingan }\end{array}$ \\
\hline
\end{tabular}

Hasil dari perbandingan pada Tabel 1 menghasilkan temuan utama dan temuan lain penelitian seperti pada Tabel 2 dan 3 berikut.

Tabel 2. Temuan Utama Penelitian 


\begin{tabular}{|l|l|}
\hline \multicolumn{2}{|c|}{ Temuan Utama Penelitian } \\
\hline Level Penalaran Proporsional & $\begin{array}{l}\text { Karakteristik Lain dari Subjek FAN, } \\
\text { ABW, LR, dan IUH yang Sama }\end{array}$ \\
\hline $\begin{array}{l}\text { Subjek FAN, ABW, LR, dan IUH } \\
\text { menempati penalaran } \\
\text { proporsional level } 2 \text { yang } \\
\text { sesuai dengan indikator dari } \\
\text { level penalaran proporsional } \\
\text { 1. Menggunakan hasil perhitungan } \\
\text { untuk menjawab soal mengenai } \\
\text { bantuan media gambar } \\
\text { 2. Bisa membuat bentuk perbandingan } \\
\text { dengan menggunakan rasio dalam } \\
\text { (within ratio) } \\
\text { 3. Tidak bisa membuat bentuk } \\
\text { perbandingan dengan menggunakan } \\
\text { rasio antara (between ratio) } \\
\text { 4. Tidak sepenuhnya memahami } \\
\text { hubungan invarian dan kovarian }\end{array}$ \\
\hline
\end{tabular}

Tabel 3. Temuan Lain Penelitian

\begin{tabular}{|l|l|l|l|}
\hline \multicolumn{4}{|c|}{ Temuan Lain Penelitian } \\
\hline \multicolumn{2}{|c|}{ Karakteristik Lain dari Subjek FAN, ABW, LR, dan IUH yang berbeda) } \\
\hline Subjek FAN & Subjek ABW & \multicolumn{1}{|c|}{ Subjek LR } & Subjek IUH \\
\hline - Menggunakan & Dapat & Menggunakan & - Menggunakan \\
hasil perhitungan & menggunakan & hasil & bantuan tabel \\
untuk menjawab & bantuan tabel & perhitungan & dengan \\
soal mengenai & dengan & untuk & terlebih dahulu \\
bantuan media & terlebih dahulu & menjawab soal & mencari \\
tabel & mencari nilai & mengenai & pecahan \\
Mengetahui & satuannya & bantuan media & senilainya \\
bentuk & sebagai faktor & tabel & kemudian \\
perbandingan & pengalinya & & melipatgandak \\
tetapi tidak & & & an \\
menggunakannya & & & - Kurang tepat \\
dalam & & & dalam \\
memecahkan & & & menggunakan \\
masalah & & & bentuk \\
perbandingan & & & perbandingan \\
Menggunakan & & & untuk \\
intuisi atau & & & memecahkan \\
perasaan dalam & & & masalah \\
memecahkan & & & perbandingan \\
masalah & & & \\
perbandingan & & & \\
\hline
\end{tabular}


Karakteristik dari subjek QQ dan AW yang valid dapat dilihat pada Tabel 4 berikut.

Tabel 4. Perbandingan Karakteristik dari Subjek QQ dan AW

\begin{tabular}{|l|l|}
\hline \multicolumn{1}{|c|}{ Subjek QQ } & \multicolumn{1}{c|}{ Subjek AW } \\
\hline 1. Menggunakan hasil perhitungan untuk & 1. Menggunakan tabel \\
menjawab soal mengenai bantuan media & dalam menyelesaikan \\
gambar & masalah \\
2. Menggunakan bantuan tabel dengan & 2. Menggunakan \\
terlebih dahulu mencari nilai satuannya & pecahan senilai \\
sebagai faktor pengalinya & dalam menyelesaikan \\
3. Menggunakan nilai satuan dalam & masalah \\
memecahkan masalah perbandingan & perbandingan \\
4. Menggunakan pecahan senilai dalam & 3. Menggunakan nilai \\
memecahan masalah perbandingan & satuan dalam \\
5. Bisa membuat bentuk perbandingan & menyelesaikan \\
dengan menggunakan rasio dalam (within & masalah \\
ratio) & perbandingan \\
6. Tidak bisa membuat bentuk perbandingan & 4. Menggunakan \\
dengan menggunakan rasio antara & perkalian silang \\
(between ratio) & dalam menyelesaikan \\
7. Tidak sepenuhnya memahami hubungan & masalah \\
invarian dan kovarian & perbandingan \\
8. Mengetahui bentuk perbandingan dan & 5. Tidak sepenuhnya \\
dapat menggunakannya dengan perkalian & memahami hubungan \\
silang dalam memecahkan masalah & invarian dan kovarian \\
perbandingan & \\
9. Mengetahui bahwa seluruh bentuk & \\
perbandingan akan menghasilkan jawaban & \\
yang sama & \\
\hline
\end{tabular}

Hasil dari perbandingan pada Tabel 4 menghasilkan temuan utama dan temuan lain penelitian seperti pada Tabel 5 dan 6 berikut.

Tabel 5. Temuan Utama Penelitian

\begin{tabular}{|l|l|}
\hline \multicolumn{2}{|c|}{ Temuan Utama Penelitian } \\
\hline Level Penalaran Proporsional & $\begin{array}{l}\text { Karakteristik Lain dari Subjek QQ dan } \\
\text { AW yang Sama }\end{array}$ \\
\hline $\begin{array}{l}\text { Subjek QQ dan AW menempati } \\
\text { penalaran proporsional level 3 } \\
\text { yang sesuai dengan indikator dari } \\
\text { level penalaran proporsional }\end{array}$ & $\begin{array}{l}\text { Menggunakan bantuan tabel dengan } \\
\text { terlebih dahulu mencari nilai } \\
\text { satuannya sebagai faktor pengalinya }\end{array}$ \\
\hline
\end{tabular}


Tabel 6. Temuan Lain Penelitian

\section{Temuan Lain Penelitian}

(Karakteristik Lain dari Subjek QQ dan AW yang Berbeda)

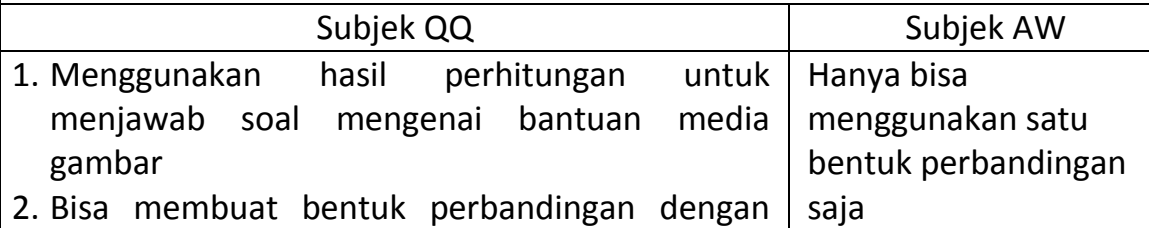
menggunakan rasio dalam (within ratio)

3. Tidak bisa membuat bentuk perbandingan dengan menggunakan rasio antara (between ratio)

4. Mengetahui bahwa seluruh bentuk perbandingan akan menghasilkan jawaban yang sama

Berdasarkan hasil temuan utama dan temuan lain pada level 2 dan 3, maka dapat dirumuskan hasil temuan utama dan temuan lain penelitian sebagai berikut.

\section{Hasil Pembahasan Temuan Utama}

Dalam penalaran proporsional terdapat empat level dengan karakteristik yang berbeda-beda. Pada level 2, ternyata siswa sudah mampu memahami rasio sebagai gabungan antara dua kuantitas yang berbeda. Siswa mampu menggunakan bilangan dalam membentuk suatu perbandingan dan mampu memanipulasi rasio tersebut untuk memecahkan masalah perbandingan dengan menggunakan tabel, pecahan senilai, perkalian skalar, maupun menggunakan nilai satuan. Pada saat mengerjakan mengenai masalah kualitas dalam hal ini perbandingan rasa, ternyata siswa cenderung menggunakan pecahan senilai, tetapi ketika dihadapkan pada soal mengenai kuantitas dalam hal ini perbandingan harga, siswa lebih mengarah pada mencari nilai satuan. Hal ini senada dengan hasil penilitian yang dilakukan oleh Park dkk (2010) yang mengemukakan bahwa strategi yang digunakan siswa tergantung dari konteks masalah yang diberikan.

Ketika siswa dihadapkan pada suatu bentuk perbandingan, ternyata siswa mengacu pada soal yang diberikan. Hal ini terlihat ketika siswa hanya mengetahui bentuk perbandingan dengan menggunakan rasio dalam (within ratio), tetapi tidak mengetahui bentuk perbandingan menggunakan rasio antara (between ratio). Hal yang sama juga diungkapkan oleh Walle (2007), dimana kesulitan terbesar 
siswa adalah membuat sebuah perbandingan yang benar dari dua rasio, salah satunya mencakup nilai yang belum diketahui. Dengan demikian, dapat dikatakan bahwa siswa tidak sepenuhnya memahami hubungan invarian dan kovarian.

Pada level 3, siswa mengetahui bentuk perbandingan dan dapat menggunakan bentuk perbandingan tersebut untuk memecahkan masalah dengan perkalian silang. Sama halnya seperti level 2, strategi pemecahan masalah yang digunakan juga tergantung pada masalah yang diberikan. Siswa pada level 3 ternyata tidak sepenuhnya memahami hubungan invarian dan kovarian karena siswa hanya mampu menggunakan satu bentuk perbandingan yaitu bentuk perbandingan dengan menggunakan rasio dalam (within ratio) atau rasio antara (between ratio) saja. Berdasarkan hal ini, terlihat bahwa siswa pada level 3 tidak sedang berada pada level 3, melainkan sedang dalam tahap transisi atau perpindahan dari level 2 ke level 3. Hal ini dikarenakan, level 3 merupakan level tertinggi dimana siswa harus memiliki pemahaman prosedural dalam hal ini menggunakan aturan perkalian silang, maupun pemahaman konseptual yaitu sepenuhnya memahami hubungan invarian dan kovarian.

2. Hasil Pembahasan Temuan Lain

Dalam penalaran proporsional level 2 ternyata ditemukan tiga strategi pemecahan masalah perbandingan menggunakan bantuan tabel yaitu: (1) mencari pecahan senilainya terlebih dahulu kemudian melipatgandakan pecahan senilai tersebut sampai diketahui solusinya, (2) mencari nilai satuannya terlebih dahulu kemudian mengalikan nilai satuan tersebut dengan angka yang sudah diurutkan sampai menemukan hasil jawaban, (3) terlebih dahulu memecahkan masalah yang diberikan dengan menggunakan strategi lain, kemudian siswa mengisi tabel dengan menyusun angka yang sesuai dengan kolom dan baris tabel.

Pada penalaran proporsional level 2, ditemukan hal menarik yaitu siswa tidak menggunakan bantuan media gambar dalam memanipulasi situasi perbandingan yang dihadapi, tetapi langsung menggunakan bilangan. Padahal menurut DeCorte dkk (dalam Nunokawa, 2012: 233), penggunaan media gambar sangat membantu dalam merubah pemahaman informal menjadi formal. Pada saat menggunakan tabel, 
secara tidak langsung siswa bisa menggunakan media gambar, hal ini dikarenakan angka-angka yang ada pada tabel ternyata merupakan representasi dari media gambar. Penggunaan media gambar bertujuan untuk menanamkan konsep awal mengenai perbandingan sebelum dikenalkan pada prosedur algoritmis. Hal senada juga dijelaskan oleh Walle (2007) dimana dalam mengenal suatu perbandingan diharapkan siswa tidak langsung menghasilkan keterampilan atau prosedur algoritmis. Hal menarik lainnya yaitu ketika siswa sudah mengetahui mengenai bentuk perbandingan, tetapi tidak menggunakan bentuk perbandingan tersebut dalam memecahkan masalah dan lebih cenderung menggunakan stategi informal untuk memecahkan masalah perbandingan. Vincent (2009) mengungkapkan bahwa, siswa melakukan beberapa pengandaian dalam bernalar, dan tidak mesti menggunakan algoritma yang sudah diketahui. Walle (2007), juga mengemukakan bahwa siswa pada kelas VII jarang menggunakan metode perkalian silang untuk memecahkan masalah proporsi, meskipun metode perkalian silang telah diajarkan.

Dalam memecahkan masalah perbandingan mengenai kualitas yaitu perbandingan rasa, ternyata siswa level 2 ada yang menggunakan perasaan yaitu tidak menggunakan perbandingan secara perhitungan, tetapi lebih mengarah kepada rasa. Hal tersebut sangat bertentangan ketika dihadapkan pada masalah perbandingan yang berkaitan dengan kuantitas yaitu perbandingan harga, ternyata siswa menyelesaikan dengan menggunakan nilai satuan. Dengan demikian penalaran proporsional mengenai masalah kualitas maupun kuantitias dapat terjadi perbedaan, karena siswa tidak hanya berpikir mengenai perbandingan, tetapi juga berpikir mengenai perasaan.

Dalam penalaran proporsional transisi level 2 ke level 3 ternyata ditemukan dua strategi pemecahan masalah perbandingan menggunakan bantuan tabel yang hampir sama dengan level 2 yaitu: (1) Melipatgandakan nilai yang sudah diketahui untuk menemukan solusinya. (2) Mencari nilai satuannya terlebih dahulu yang kemudian mengalikan nilai satuan tersebut dengan angka yang sudah diurutkan sampai ditemukan hasil jawabannya. Ditemukan pula subjek yang menggunakan hasil perhitungan untuk menjawab soal mengenai bantuan media gambar. 
Pada transisi level 2 ke level 3, siswa hanya memahami satu bentuk perbandingan, yaitu bentuk perbandingan menggunakan rasio dalam (within ratio) atau rasio antara (between ratio). Indikasi lain yang memperkuat hal tersebut yaitu dengan menggunakan perkalian silang, ternyata siswa mengetahui bahwa bentuk perbandingan yang diberikan menghasilkan nilai yang sama, tetapi ketika dihadapkan untuk memilih bentuk perbandingan, siswa hanya terfokus pada satu bentuk perbandingan saja dan menganggap bentuk perbandingan yang lain kurang tepat.

\section{Simpulan}

Berdasarkan penelitian yang dilakukan pada enam subjek siswa kelas VII SMP Negeri Tasikmadu, terdapat empat orang yang termasuk dalam penalaran proporsional level 2 dan dua orang termasuk transisi level 2 ke level 3. Penalaran proporsional level 2 yaitu siswa sudah bisa bernalar kuantitatif, artinya yaitu mampu memanipulasi situasi perbandingan dengan menggunakan suatu bilangan. Siswa pada level 2 sudah bisa menganggap dua kuantitas jika digabungkan akan menjadi satu kesatuan. Transisi level 2 ke level 3 yaitu siswa dikatakan termasuk ke dalam level 2 dan memiliki sebagian karakteristik dari level 3.

Transisi level 2 ke level 3 terjadi karena pada dasarnya untuk mencapai level 3, siswa harus memiliki pemahaman prosedural dalam hal ini yaitu strategi pemecahan masalah perbandingan yaitu menggunakan perkalian silang, dan pemahaman konseptual yaitu sepenuhnya memahami hubungan invarian dan kovarian. Ternyata didapatkan dua subjek hanya bisa menggunakan strategi formal yaitu menggunakan perkalian silang, tetapi tidak sepenuhnya memahami hubungan invarian dan kovarian. Pada transisi level 2 ke level 3, siswa bisa menggunakan prosedur perkalian silang untuk memecahkan masalah perbandingan, tetapi belum mengetahui perbandingan dengan menggunakan rasio dalam (within ratio) ataupun rasio antara (between ratio). Siswa hanya terfokus pada satu bentuk perbandingan dan tidak mengetahui bentuk perbandingan yang lain.

Adapun saran dari hasil penelitian ini adalah kepada peneliti lain apabila ingin melakukan penelitian sejenis dapat menggunakan subjek yang 
lain, mencari keseluruhan level penalaran proporsional, menggunakan bermacam-macam masalah, atau melakukan eksperimentasi.

\section{Daftar Pustaka}

Kilpatrick, J., Swafford, J., \& Findell, B. (2001). Adding it up: Helping children learn mathematics. Washington D.C.: National Academy Press.

Langrall, C. W., \& Swafford, J. (2000). Three ballons for two dollars. Mathematics Teaching in the Middle School. The National Council of Teachers of Mathematics, Inc. Diunduh dari http://math.buffalostate. edu/ wilsondc/MED\%20308/ProportionalThinkingMTMS.pdf

Moleong, L.J. (2012). Metodologi penelitian kualitatif. Bandung: PT Remaja Rosdakarya.

Nunokawa, K. (2012). Multi-Relation Strategy in Students' Use of a Representation for Proportional Reasoning. Eurasia Journal of Mathematics, Science \& Technology Education. 8(4): 233-248.

Park, J.H., \& Kwon, O.N. (2010). Characterizing the proportional reasoning of middle school students. SNU Journal of Education Research, 19 (5), 199-144. Diunduh dari http://s-space.snu.ac.kr /bitstream/10371/72999/1/vol19 5.pdf

Singh, P. (2010). Understanding the concepts of proportion and ratio constructed by two grade six students. Educational Studies in Mathematics, 43 (3), 271-292. Diunduh dari http://coe.utep.edu/ ted/images/academic programs/graduate/pdfs/matharticles/proportiona \%20reasoning\%20Singh.pdf

Sujadi, I. (2010). Tingkat-tingkat berpikir probabilistik siswa Sekolah Menengah Pertama. Disertasi: Universitas Negeri Surabaya.

Sutopo, H. B. (2006). Metodologi Penelitian Kualitatif edisi kedua. Surakarta: Universitas Sebelas Maret.

Vincent, C. (2009). Ratio and proportion: Mapping the conceptual field. Tesis. Louisiana State University. Diunduh dari http://etd.Isu.edu/ docs/available/etd-07092009100847/unrestricted/vincentthesis.pdf

Walle, J. V. (2007). Matematika sekolah dasar dan menengah pengembangan pengajaran. Jakarta: Erlangga. 